\title{
Evaluation of Aluminium Production Waste in Building Material Production
}

\author{
Mustafa Dereli ${ }^{\circledR}$, Mustafa Tosun $\odot 2$ \\ ${ }^{1}$ Res. Asst. Dr., Faculty of Architecture and Design, Konya Technical University, Konya, Turkey. (Principal contact for editorial \\ correspondence), Email: mdereli@ktun.edu.tr \\ ${ }^{2}$ Prof. Dr., Faculty of Architecture and Design, Konya Technical University, Konya, Turkey. Email: mtosun@ktun.edu.tr
}

\begin{abstract}
Purpose

The production of aluminum is based on obtaining alumina from bauxite, which is also known as the "Bayer Process." However, waste that is enough to endanger the environment is released at the end of this process applied to obtain aluminum. In Turkey, red mud waste is released from Seydișehir ETI Aluminum production facilities into the pond located within the settlements. Red mud, which creates a potential environmental problem, should be systematically eliminated. In the literature, there are hundreds of studies on this subject. However, it is observed that these studies will not accelerate the waste consumption process. The consumption of the waste as soon as possible will be possible by using it as the main raw material. In this context, using both the literature and the doctorate study of the manuscript's author, the methods for using the waste as a building material were discussed for the systematic consumption of it.

Design/Methodology/Approach

Accordingly, in the study, the physical (specific gravity, plastic limit, differential thermal analysis, etc.) and chemical properties (XRF) of the waste red mud were discussed together with the waste generation process starting with the Bayer process. Furthermore, the physical (specific gravity, water absorption, water vapor permeability, initial water absorption velocity), mechanical (compressive strength) of the building materials that could be produced by using the waste were also included in the study.

Findings
\end{abstract}

It was concluded that it was possible to produce a quality building material by using the waste as a raw material.

\section{Research Limitations/Implications}

Type the research limitations/implications of the paper here.

The study was limited to the mixing of red mud waste and pyroclastic rocks in certain proportions and their use as raw materials in the production of baked building materials by baking at different temperatures.

\section{Social/Practical Implications}

In this study, a solution method to a potential environmental problem was developed. Furthermore, a source of raw material was provided in sustainable building material production. Accordingly, a contribution can be made to the national economy with the building material that can be produced with local opportunities.

\section{Originality/Value}

With the materials and joining methods used in the study, a production was made on a unique subject. 


\section{INTRODUCTION}

Red mud is a waste that remains as a result of the method of obtaining alumina from bauxite, known as the Bayer process (Saternus, 2011). This waste, which is formed as a result of a chemical process, can also be called hazardous waste (Saternus, 2011). In the process, 2 units of alumina are obtained from 4 units of bauxite, while 2 units of waste called red mud is generated and left to nature as waste at the end of the process (Dereli \& Tosun, 2020). Red mud waste is kept in artificial ponds in nature. Waste ponds built in the basins are used for the Seydişehir ETI Aluminum Factory. The second pond built for the factory is used. The pond is filled with tons of sludge. The pond located right next to the settlements poses a potential threat to the environment. In the city of Ajka, Hungary, with the collapse of one of the banks of the pond where the red mud was stored, the waste spread many kilometers away and turned into an environmental disaster (Winkler et al., 2018). The systematic consumption of waste has become a necessity in order to prevent such an environmental disaster from happening again. In this direction, hundreds of studies have been done in the literature. While some of them are in the direction of making use of it as an additional contribution to production of brick (Arroyo et al., 2020), ceramic (Xiang et al., 2020), cement (B. Yuan et al., 2020), geopolymer (Zhang et al., 2020) etc., some of them are in the direction of obtaining iron from the waste in terms of its chemical content (S. Yuan et al., 2020), treatment of waste waters (Li et al., 2020) and its use for different purposes with chemical reactions (Wang et al., 2020). However, the general feature of the studies is that the waste red mud is used only in small amounts as an additive. With this general feature, it will not be possible to provide the targeted process for the systematic consumption of waste.

From this point of view, it is planned to use red mud as the main raw material at a high rate in the study, and to keep the additives to be made in a way to improve the properties of red mud and keep it in low proportions. The color and texture of the waste mud and its similarity to clay have led to its use in brick production. Considering that the use of red mud alone may increase the cost of brick production, it seemed appropriate to add micronized pyroclastic to the waste, which is also obtained from idle fields. In this way, it is aimed to obtain an artificial clay and to reach decreasing values in cooking temperatures. Micronized pyroclastic rocks for the development of artificial clay properties have been obtained from abandoned inert fields since they have no economic value. Accordingly, 4 different volcanic based materials were used: Campus Volcanic Tuff (CT), Selahattin Village Volcanic Tuff (SVT), Karapınar Region Red Basaltic Slag (KRS), Karapınar Region Black Basaltic Slag (KBS).

In the study, the physical and mechanical properties of the brick produced by adding micronized pyroclastic rocks to red mud at different rates were investigated and its suitability for high density brick production according to the standards was tested. It has been accepted 
that the sample type that gives the best strength results with the experiments is the optimum mixture type that can be used in brick production. At the same time, results were obtained whether it is possible to evaluate inert pyroclastic fields with the results obtained with other mixture types. In this way, it has been researched that both waste material and inert pyroclastic material can be used together in the production of a sustainable building material.

\section{MATERIAL AND METHOD}

In this chapter, information about raw materials and their properties are given. Also, production of test specimens using raw materials and test methods are explained in detail.

\section{Raw Materials}

The definition of raw materials, red mud and pyroclastic rocks, their locations, physical and chemical properties are discussed in this chapter.

\section{Red mud (RM)}

Red mud is a waste generated during the production of alumina (Al203). In 1887, K.J. Bayer's Bayer process method, which enables to obtain alumina from bauxite, emerged. Accordingly, bauxite, which is the raw material of alumina, reacts with sodium hydroxide and becomes aluminate [ $\mathrm{NaAl}(\mathrm{OH}) 4]$. Aluminum hydroxide is formed by dissolving under 950-1200 oC temperature and pressure. During this process, insoluble iron, silicon and titanium sink to the bottom. This precipitated waste product is called red mud (Arslan et al., 2012). Red mud for this research was obtained from the waste pond (37o27'39.09" N latitude, 31048'43.00" E longitude) of ETİ Aluminum factory in Konya-Seydişehir. Factory; uses the second of the waste ponds built in the basins.

\section{Pyroclastic rock}

Pyroclastic rocks can form in many ways as culms ejected from chimneys due to volcanic eruption. Hydroclastic clastic is formed by steam eruption, rapid cooling or mechanical granulation of the lava in the parts that are in contact with magma and water. Hydroclastic cullet is a type of pyroclastic rock. Apart from chimney or hydroclastic fragments, volcanic rocks decomposition and transport (epiclastic), mechanical friction during lava movement or gaseous eruptions (autoclastic) fragments also occur. Another formation is seen in the form of fragmentation by tectonism. Pyroclastic rocks include all clastic volcanic rocks that have undergone any process of disintegration, have been moved or mixed with other non-volcanic fragments. The term volcanoclastic, which appears in the literature, is synonymous with pyroclastic. The terminological use is considered to be pyroclastic rock, regardless of other processes that were formed directly by volcanic means, such as water or wind, that may carry the fragments later. Pyroclastic eruption products are formed in three 
different ways: juvenile (main), cognate or incidentally (Helvacı \& Erkül, 2001). Pyroclastic rocks from different regions were used in the study.

Konya Selahattin Village Volcanic Tuff (SVT): The inert tuff field of the samples used in the study is around the Selahattin Village between Derbent District and Konya Province. Accordingly, the coordinates of the sample location taken from the inactive tuff field are 3801'7.94" $\mathrm{N}$ latitude, 32o8'40.55" E longitude.

Konya Selçuk University Campus Surroundings Volcanic Tuff (CT): The inert tuff field is located in Konya-Selcuklu district, around Selcuk University Alaaddin Keykubat Campus. The samples were taken from the inactive tuff field at 3802'8.96" N latitude, 32o28'13.07" E longitude coordinates to be used in the study.

Konya Karapınar Region Basaltic Slag: Basalt type rocks are formed from two kinds of movements of volcanism. Such rocks are formed during lava flows or eruptions. The basalts formed as a result of these two volcanic movements gain diversity in the form of ash, slag and blocks. Especially around Lake Meke, there are slag cones formed by lava flows. Slag covers, which are black or dark gray in color, can also form red colored layers with oxidized iron content. The thickness of the plates varies between 1-6 m. It is possible to encounter white carbonates in the black basalt as a result of the infiltration and circulation of surface waters. The slags in the region are spongy in appearance (Olanca, 1999). The basaltic slag samples were taken from Karapınar District of Konya Province. It is located between 37o40'18.31" N latitude and 33o41'46.24" E longitude according to the coordinate system. Since the samples obtained from the region were in two different colors, basaltic slag was divided into groups according to colors in the study.

Karapınar Region Red Basaltic Slag (KRS): In the area where the samples were obtained, red colored layers were formed in places due to the oxidized iron content. For this reason, red colored slags were used as a different material in this study with this title denomination.

Karapınar Region Black Basaltic Slag (KBS): Two colored stratifications were formed in the slag quarry of Karapınar region. The characteristic color of the slag is dark gray-black. Black basaltic slag is mentioned with this denomination during raw material and sample production stages.

\section{Method}

\section{Determination of the raw material characteristics}

The chemical analysis, grain density, plastic limit and thermogravimetric analyzes of the raw materials to be used in the production of a baked building material were determined by a preliminary study.

Chemical Analysis (XRF- X Ray Fluorescence): The elemental properties of red mud waste were taken from the literature. The chemical analyzes of the pyroclastic rocks were carried out in the R\&D laboratory of the Kütahya Ceramic Factory. Accordingly, in the analyzes, the method specified in the standard "Characterization of Waste And Soil - 
Determination of Elemental Composition With X-ray Fluorescence" and Spectro X-LAB 2000 (400-W Rh end window tube and Si (Li) detector with a resolution of $148 \mathrm{eV}(1000 \mathrm{cps} \mathrm{Mn} \mathrm{K \alpha})$ ) was used (TS_EN_15309, 2008).

Grain Density: The experiment was carried out in Konya DSI 4th Regional Directorate, Laboratory and Quality Control Branch Directorate, Soil Laboratory using the "liquid pycnometer method" specified in the standard named "Determination of Grain Density" (TS_EN_ISO_17892-3, 2016). Two experiments were carried out for each type of raw material.

Plastic Limit Value: The experiment was determined by the experiment conducted in Konya DSI 4th Regional Directorate, Laboratory and Quality Control Branch Directorate, Soil Laboratory, in accordance with the method described in the standard named "Soil Laboratory Tests in Civil Engineering: Determination of Physical Properties" (TS 1900-1) (TS_1900-1, 2006) . Since the plastic limit value was made twice, the plastic limit value of the raw materials was calculated by taking the average.

Thermogravimetric Analysis (TGA): The analysis was carried out at Selcuk University Advanced Technology Research and Application Center. "Mettler Toledo" brand device with "TGA/DSC 1Thermogravimetric Analysis" feature was used. The inside of the device furnace used in TGA analysis provides an atmosphere with dry air. It was heated to approximately $1100^{\circ} \mathrm{C}$ for 2 hours with a temperature rise rate of $10{ }^{\circ} \mathrm{C}$ per minute (TS_EN_ISO_11358-1, 2014).

\section{Production of experiment samples}

Samples were prepared by the method described below to be used in the experiments.

Grinding: The grinding process was carried out in the Mining Engineering Laboratory of Konya Technical University. The rocks were ground in a steel ball mill produced by Ünal Engineering and Machine Industry to pass under a 100 micron sieve. Before grinding, the materials were oven-dried at $105 \pm 5$ oC for 24 hours (Dereli \& Tosun, 2020).

Mixing and Remolding: In the production of samples to be used in the experiments, pure red mud and samples produced by adding different percentages of pyroclastic rock to the main raw material as red mud are used. The primary purpose was to use red mud in high proportions and thus make it possible to consume the waste. Therefore, it was decided to test the pure red mud as it is to determine the potential of the baked building material. Using the material as it is in its natural environment with this method will provide economic gains. In order to learn the behavior of red mud against the effect of temperature, "pure red mud is taken as it is and remolded" was chosen as the first sample type. For other mixtures, micronized pyroclastic rock was added as 10\%, $20 \%, 30 \%$, $40 \%, 50 \%$ by weight compared to red mud. In the amount of material to be used in the mixtures, the "weight percent ratio in dry material" method was chosen. With these additions, it is aimed to determine the changes 
made by different cooking temperatures in physical properties or mechanical properties, and in this way, to reach an optimum mixing ratio in the production of a material with high mechanical strength. Plastic consistency water is needed in the production of baked building materials. In this respect, it has been seen that the red mud is in the water in the environment where it is found as a waste, it is possible to use this raw material together with its water content, and at the same time, water savings will be achieved (Dereli \& Tosun, 2020).

Molding: Since the waste materials to be used in the production of test samples have a clay-like structure used in baked building materials, the molding forms used in this field were targeted as a method in sample production.

In the compressive strength test to be performed on the samples, it was deemed appropriate to choose a method from a standard suitable for similar sample types. For the laboratory-type filled sample, the $5 \times 5 \times 5 \mathrm{~cm}$ cube samples specified in the standard "Standard Test Method for the Compressive Strength of Hydraulic Cement Mortars Using 50-mm Cube Samples" (ASTM_C109, 2001) were seen to be similar. In this direction, plaster molds were made to produce samples in these dimensions. Considering that there will be a change in the dimensions of the samples after drying-shrinking and baking-shrinking, these molds were manufactured with the inner dimensions of 5,5x5,5x5,5 cm.

Baking: Preliminary trials were made for optimum temperature values due to the different contents of the samples. First, the minimum temperature required for baking the red mud in its pure form was determined. In this way, it was thought that it would be possible to bake samples at lower temperatures than this temperature value with the addition of pyroclastic (Dereli \& Tosun, 2020).

\section{Preliminary evaluations on samples and selection of samples to be used in experiments}

Hundreds of samples were prepared as described above. Volume stability, mechanical strength, etc. on the prepared samples. values were analyzed. At the end of the investigations, two types of mixtures with high strength properties compared to the type formed by the addition of pyroclastic obtained from all different regions were selected to be used in the experiments to be made in terms of the properties of the baked building material (Dereli \& Tosun, 2020).

\section{Experiments on samples}

The experiments described below were carried out on the samples.

Net Dry Density: In order to determine the net dry density values, the method specified in the standard named "Determination of net and gross dry unit volume masses of masonry units (excluding natural stone)" was used. Accordingly, the net volumes of 12 samples were calculated for each type of mixture with dimensions of $50 \times 50 \times 50 \mathrm{~mm}$ with smoothed surfaces and they were made ready for the experiment (TS_EN_772-13, 
2002). The lowest and highest results were obtained from the net dry density values obtained from 12 samples for each species, and the arithmetic average of the other values was taken.

Water Absorption Test: The test was conducted with the water absorption test method described in the standards named "Natural Building Blocks-Examination and Test Methods" and "Clay Masonry Units-Properties" (TS_699, 2009; TS_EN_771-1, 2005). The water absorption test was carried out in two parts: by mass and by volume.

- Water Absorption by Mass: The dry weight of the sample is needed to calculate the rate of water absorption by mass. For this reason, the water-saturated samples were dried in an oven for 24 hours. The samples taken out of the oven were cooled in a desiccator and weighed on a scale with an accuracy of $0,01 \mathrm{~g}$. The formula given in the standard was used to determine the water absorption rates of the samples whose weighing processes were completed (TS_699, 2009; TS_EN_771-1, 2005). The lowest and highest results were excluded from the water absorption values obtained from 12 samples used for all different types, and the arithmetic average of the other values was taken.

- Water Absorption by Volume: In the water absorption experiment by volume, the data obtained in the water absorption experiment by mass were used. In addition, the weight of the samples in water was determined by Archimedes balance. With the obtained data, calculations were made with the help of the formula given in the standard. For each type of sample, the lowest and highest values of water absorption by volume obtained from 12 samples were excluded and the arithmetic average of the other values was taken.

Fill (Compactness) Rate: Fill rate of materials is known as the ratio of unit volume weight to specific weight. Accordingly, the percentage value of the ratio of the net dry density of the samples to the actual density was calculated with the help of the formula in TS 699 (TS_699, 2009).

Porosity Degree: The sum of the porosity rate and the filling rate constitutes the whole of the materials. In this direction, porosity degrees were calculated with the formula in the standard named "Natural Building Blocks-Examination and Test Methods" (TS_699, 2009).

Initial Water Absorption Rate: The "initial water absorption rate" experiment was carried out on samples according to the standard named "Masonry units - Test methods - Part 11: Determination of capillary water absorption in masonry units made of concrete, artificial and natural stone and initial water absorption rate in clay masonry units". Accordingly, for the experiment, at least three samples were dried in an oven and the surface area to absorb water was measured. It is covered with paraffin to prevent water absorption from the side surfaces. The final dry weight of the paraffin-coated sample was weighed and recorded with a balance with an accuracy of 0,01 g. By measuring the amount of water entering the samples within 1 minute, the initial water absorption rates were 
calculated with the help of the formula given in the standard (TS_EN_77211, 2002).

Compressive Strength: Experiment was carried out according to the methods in the standards named "Masonry Units-Compressive Strength" and "Test Methods of Bricks and Tiles" (ASTM_C67-11, 2011; TS_EN_7721, 2012). Compressive strength tests were carried out at DSI 4th Regional Directorate, Quality Control and Laboratory Branch Directorate, Concrete Laboratory, using the Form-Test Prufsystem device with 50x50 mm caps developed for cement sample tests. In the test for compressive strength,

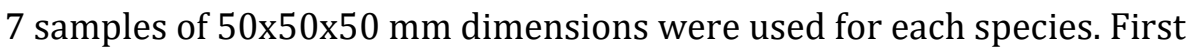
of all, the samples were dried in an oven and conditioned by cooling in a desiccator before the experiment. The standard loading rate of the device was determined as $0,60 \mathrm{~N} / \mathrm{mm} 2$. KN (Kilonewton) values given by the device at the time of fracture were recorded. Values were converted into units with the help of the formula given in the standard and recorded by making calculations. For the compressive strength values, the smallest and highest values of the 7 samples that were broken were excluded from the average calculations as deviation values. The arithmetic average of the remaining values was calculated by excluding the deviation values.

Resistance to Acid Effects: If the product samples are used in kitchens, dairy facilities, laboratories, etc. as a brick to be used as a wall material, they may be exposed to acid. For this reason, resistance tests were carried out with 4 different acids, known as very strong acids, in the laboratory environment.

For the experiment, 4 samples were prepared from each type of sample. The samples were first oven-dried and cooled in a desiccator. Then, the weights were made and recorded on a balance with a precision of 0,0001 grams. They are placed in the beaker for the acid bath. Sulfuric acid, hydrochloric acid, nitric acid and phosphoric acid were used for the acid bath. $50 \mathrm{ml}$ of acid of each type was poured onto the samples in pure form and waited in this way for 24 hours. During this period, changes on the samples were observed. At the end of 24 hours, $50 \mathrm{ml}$ of water was added to the beakers and the acids were diluted and kept in this way for another 24 hours. The damaged samples were observed and the undamaged samples were removed from the acid bath at the end of the period and left to dry. It has been determined whether the samples dried in the oven have a weight loss or not.

\section{EXPERIMENT FINDINGS AND ASSESSMENT}

Raw Material Characteristics

Chemical Analysis (XRF): Chemical analysis results for red mud and pyroclastic rocks are given in the Table 1 .

With its red color caused by high amount of oxidized iron content, waste mud has been the subject of studies for its use in the production of baked building materials such as bricks and etc. In this study, based on this idea, it has been seen that it is possible to obtain an artificial clay not only as a color but also with pyroclastic to be mixed into it. 
Evaluation of Aluminium Production Waste in Building Material Production

Table $1 . \mathrm{XRF}$ analysis of red mud and pyroclastic rocks

\begin{tabular}{cccccc}
\hline COMPONENT & \% (RM) & \% (SVT) & \% (CT) & \% (KRS) & \% (KBS) \\
\hline $\mathrm{Na}_{2} \mathrm{O}$ & 5,79 & 3,96 & 0,88 & 3,08 & 2,1 \\
\hline $\mathrm{MgO}$ & 0,26 & 1,58 & 2,04 & 6,15 & 6,39 \\
\hline $\mathrm{Al}_{2} \mathrm{O}_{3}$ & 21,08 & 14,79 & 15,16 & 15,31 & 17,13 \\
\hline $\mathrm{SiO}_{2}$ & 15,58 & 68,8 & 67,39 & 47,2 & 51,23 \\
\hline $\mathrm{P}_{2} \mathrm{O}_{5}$ & 0,04 & 0,05 & 0,15 & 0,22 & 0,27 \\
\hline $\mathrm{SO}_{3}$ & 0,56 & 0,07 & 0,06 & 0,04 & 0,03 \\
\hline $\mathrm{K}_{2} \mathrm{O}$ & 0,61 & 4,57 & 2,93 & 0,78 & 0,07 \\
\hline $\mathrm{CaO}$ & 2,71 & 5,12 & 3,8 & 9,94 & 10,32 \\
\hline $\mathrm{TiO}_{2}$ & 4,62 & 0,17 & 0,43 & 0,98 & 1,03 \\
\hline $\mathrm{MnO}^{\mathrm{Fe}} \mathrm{O}_{3}$ & 0,03 & 0,08 & 0,06 & 0,13 & 0,15 \\
\hline Ignition Loss & 30,37 & 1,53 & 4,27 & 9,64 & 9,88 \\
\hline$\%$ ) & 15,66 & 17,54 & 15,50 & 1,06 & 6,35 \\
\hline
\end{tabular}

- Grain density: Grain densities of the raw materials determined by the calculations made at the end of the experiments, each repeated twice, are given in Table 2.

-Plastic limit: The results obtained at the end of the plastic limit tests are given in Table 2. Accordingly, there is no plastic feature in other raw materials except red mud.

Table 2. Grain density and plastic limit values of raw materials

\begin{tabular}{lccccc}
\hline & RM & SVT & CT & KRS & KBS \\
\hline Grain Density & 23 & 2,58 & 2,64 & 2,93 & 2,72 \\
\hline Plastic Limit (\%) & 28,4 & No Value & No Value & No Value & No Value \\
\hline
\end{tabular}

Malayoğlu and Akar in their study classified the materials with 10\%-30\% plastic properties as non-clay materials and ordinary clays (Malayoğlu \& Akar, 1995). They stated that the plasticity of clays with kaolin and montmorillonite content is between $30-65 \%$, while clays with bentonite content show plasticity at values of $80 \%$ and above. Accordingly, according to the plastic limit test results for red mud, it can be said that it is a material that does not show sufficient plastic properties.

-TGA Analysis: When the TGA graphic values of the red mud were examined, it was seen that the weight loss started at 30,23 Co. The analysis was terminated when the heating temperature reached 1095,35 ${ }^{\circ} \mathrm{C}$. Partially small endothermic peaks occurred, with the first peak at 238 ${ }^{\circ} \mathrm{C}$ and the more prominent second peak at 286,33 Co. According to the results of the analysis, maximum weight loss was experienced in the range of $250-300{ }^{\circ} \mathrm{C}$. Total weight loss at the end of the whole period was calculated as $1,7749 \mathrm{mg}(15.66 \%)$.

According to TGA analysis of volcanic tuff (SVT) around Selahattin Village, the total weight loss was calculated as $1,2427 \mathrm{mg}$. Accordingly, the total weight loss was calculated as $17,54 \%$. At $70^{\circ} \mathrm{C}$, the first endothermic peak was formed at a high rate, at $140{ }^{\circ} \mathrm{C}$ the second peak was observed to a lesser extent, and at $468^{\circ} \mathrm{C}$ the last observed peak occurred.

According to the TGA analysis of the volcanic tuff around the Selcuk University campus (CT), a weight loss of $1,3247 \mathrm{mg}$ occurred in the 
material that started at $29,07^{\circ} \mathrm{C}$ and was heated to $1095,35^{\circ} \mathrm{C}$ for 2 hours. Accordingly, the total weight loss in the sample was calculated as $15,50 \%$. When the endothermic peaks were examined, the first peak was observed at $72{ }^{\circ} \mathrm{C}$, the second peak at $140{ }^{\circ} \mathrm{C}$ and the third peak at $690^{\circ} \mathrm{C}$. The fourth peak is partially observed in the range of $900-950^{\circ} \mathrm{C}$.

In the TGA analysis of Karapınar Region red slag (KRS), the test was started with 15,2010 mg of micronized red slag. The temperature range at which weight loss occurred was between $37,20^{\circ} \mathrm{C}$ and $1095,93{ }^{\circ} \mathrm{C}$. The weight loss after two hours is $0,1607 \mathrm{mg}$. The calculated total weight loss was calculated as $1,06 \%$. In the endothermic peak analysis, very active mobility was observed, with small amounts. The most prominent peak occurred at $660^{\circ} \mathrm{C}$.

Thermogravimeter analysis was started with a sample of 17,0962 mg micronized from black basaltic slag (KBS) taken from the Karapınar region. The temperature range at which weight loss was experienced was observed as $29,65^{\circ} \mathrm{C}$ to $975.14{ }^{\circ} \mathrm{C}$. A weight loss of 1,0853 mg occurred in the sample, which was heated for two hours. Accordingly, the total weight loss was calculated as $6,35 \%$. The most prominent endothermic peak occurred at $720^{\circ} \mathrm{C}$. An example of the graph type obtained at the end of the TGA analysis is given in Figure 1.

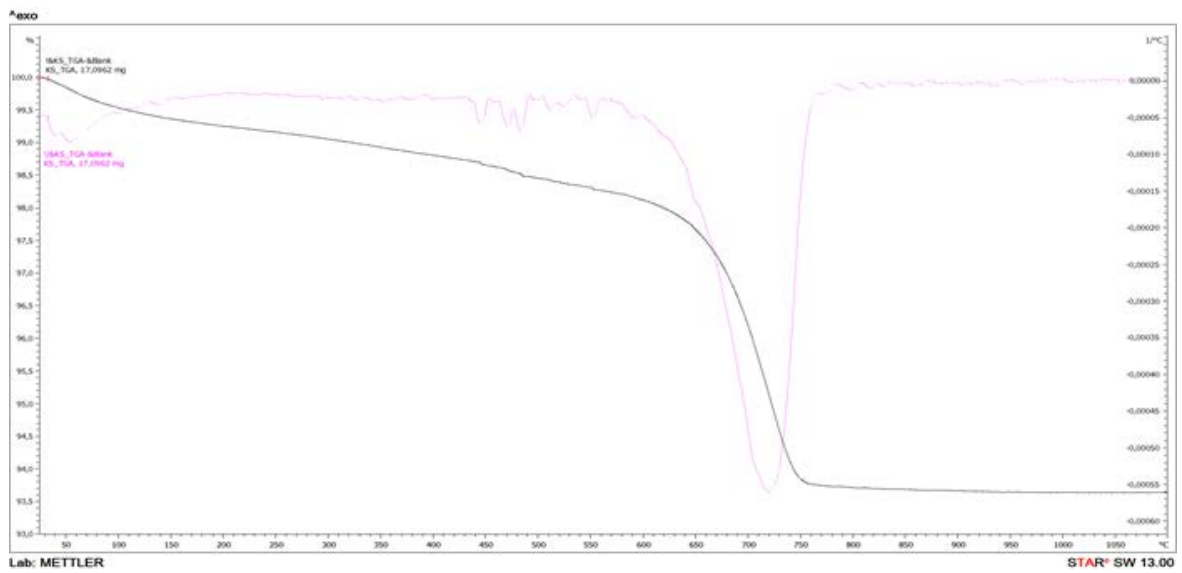

Figure 1. TGA analysis of Karapınar Region black slag

\section{Production of the Experiment Samples}

While the volcanic tuff group became oven-dry at $105 \mathrm{oC}$, this temperature was not sufficient for the basaltic slag group. Then, after calcining for the crystal water at $300-400 \mathrm{oC}$, the grinding process could be carried out.

Hundreds of samples were produced to be used in the experiments. In the first produced samples, stratifications in the form of capillary cracks were observed. It was concluded that the plastic properties of the sample mixtures were not sufficient and it was effective in these layerings. For this reason, it has been decided to add an additive to the mixture, which will be added in very small proportions and will provide plastic properties. In order to remove the observed layering, new samples were produced by adding $3 \%$ and $5 \%$ bentonite. The material named KAR-CVL (Construction bentonite- API 13 A, specified in TS EN ISO 13500, TS EN 
1536, TS EN 1538 standards) of the Karakaya Bentonite plant was used. Since there was no visible difference in the bentonite addition experiments, $3 \%$ was chosen as the amount of additive and this amount was included in the mixing ratio of all the samples to be produced next. A sample calculation to be used in determining the amount of material to be mixed is given below.

- Sample Mixture Calculation: Let's assume that the water content of $1000 \mathrm{gr}$ red mud material is analyzed and the calculated water content is $40 \%$, accordingly the amount of dry material will be 600 gr. If it is necessary to calculate with $10 \%$ pyroclastic addition, $600 \mathrm{gr}$ dry material is counted as $90 \%$ and $67 \mathrm{gr}$ material amount is calculated for $10 \%$. The total amount of dry material entering the mixture is 667 gr. Since $3 \%$ bentonite will be added in line with this result, the calculation is made using the same proportional method. Accordingly, if $667 \mathrm{~g}$ dry material is $97 \%, 3 \%$ bentonite addition amount is calculated as $21 \mathrm{gr}$ (Dereli \& Tosun, 2020).

Cube plaster molds with internal dimensions of $5 \times 5 \times 5 \mathrm{~cm}$ were successful in the study. However, since drying-shrinking and baking-shrinking will occur in the dimensions of the samples removed from the mold, the inner dimensions of the plaster molds were resized according to these factors. The average inner size of the molds was kept as $5,8 \times 5,8 \times 5,8 \mathrm{~cm}$.

The samples prepared without any additives to the red mud were baked at 1000, 1050 and 1100 degrees. In the examination made by observation, it was determined that the pure state of the red mud showed the characteristics of baked material at the limit of 1100 degrees. Upon this result, 1100 degrees was accepted as the upper limit value of baking and one sample from each mixture ratio was baked at this temperature. As the rate of pyroclastic rock addition increased at this temperature value, a high rate of reduction in volume occurred. In this direction, it was concluded that it is possible to bake at lower temperatures. Based on this result, in order to determine the optimum temperature and optimum mixing ratio of the samples to be used in the preliminary experiments, baking processes were carried out at different temperatures such as 1050,1000 and $930{ }^{\circ} \mathrm{C}$. Here, the temperature of $930{ }^{\circ} \mathrm{C}$ was specially chosen. The temperature setting of $930{ }^{\circ} \mathrm{C}$ was chosen as the closest temperature because the ovens in the laboratory did not have a suitable value for this temperature setting for the samples that are intended to be baked at $950{ }^{\circ} \mathrm{C}$.

\section{Preliminary Evaluations on Samples and Selection of Samples to be Used in Experiments}

Samples with micronized pyroclastic addition rate of $40 \%$ and $50 \%$ to red mud were excluded from the scope of the study due to high volume losses at the end of baking. In addition, the fact that the CT group dispersed at the end of the baking at $20 \%$ and $30 \%$ additional rates caused this group samples to be out of the scope of the study. On the remaining samples, 
two species from each group with different mixture types were selected that achieved the best compressive strength results. Accordingly, the samples named in Table 3 were used in the study.

Table 3. Mixing Ratios and Baking Temperatures of the Samples Used in the Experiments

\begin{tabular}{lccc}
\hline Pyroclastic Addition Type & $\begin{array}{c}\text { Addition } \\
\text { Ratio (\%) }\end{array}$ & $\begin{array}{c}\text { Baking } \\
\text { Temperature } \\
\text { (Co) }\end{array}$ & $\begin{array}{c}\text { Sample } \\
\text { Name }\end{array}$ \\
\hline Selahattin Village Tuff (SVT) & 30 & 930 & SVT 30930 \\
Selahattin Village Tuff (SVT) & 30 & 1050 & SVT 301050 \\
Campus Tuff (CT) & 10 & 1000 & CT 101000 \\
Campus Tuff (CT) & 10 & 1050 & CT 101050 \\
Karapınar Region Red Slag (KRS) & 20 & 930 & KRS 20930 \\
Karapınar Region Red Slag (KRS) & 30 & 1050 & KRS 301050 \\
Karapınar Region Black Slag (KBS) & 20 & 1050 & KBS 201050 \\
Karapınar Region Black Slag (KBS) & 30 & 1050 & KBS 301050 \\
\hline
\end{tabular}

\section{Experiments on Samples}

The results of net dry density, water absorption, compactness, porosity, initial water absorption speed and compressive strength on the selected samples are given in Table 4.

Table 4. Values of net dry density, water absorption, compactness, porosity, initial water absorption rate and compressive strength

\begin{tabular}{|c|c|c|c|c|c|c|c|}
\hline \multirow{2}{*}{$\begin{array}{l}\text { Sample } \\
\text { Name }\end{array}$} & \multirow{2}{*}{$\begin{array}{l}\text { Net Dry } \\
\text { Density } \\
\left(\mathrm{kg} / \mathrm{m}^{3}\right)\end{array}$} & \multicolumn{2}{|c|}{ Water Absorption } & \multirow{2}{*}{$\begin{array}{c}\text { Compactness } \\
\text { Ratio (\%) }\end{array}$} & \multirow{2}{*}{$\begin{array}{c}\text { Porosity } \\
\text { Ratio } \\
\text { (\%) }\end{array}$} & \multirow[b]{2}{*}{$\begin{array}{c}\text { Initial } \\
\text { Water } \\
\text { Absorptio } \\
\text { n Speed } \\
\left(\mathrm{kg} / \mathrm{m}^{2} \cdot \mathrm{mi}\right. \\
\mathrm{n})\end{array}$} & \multirow{2}{*}{$\begin{array}{c}\text { Compressi } \\
\text { ve Strength } \\
\left(\mathrm{N} / \mathbf{m m}^{2}\right)\end{array}$} \\
\hline & & $\begin{array}{l}\text { By Mass } \\
\text { Wm(\%) }\end{array}$ & $\begin{array}{c}\text { By } \\
\text { Volume } \\
\text { Wv(\%) }\end{array}$ & & & & \\
\hline SVT 30930 & 1358 & 35,13 & 48,05 & 41,21 & 58,79 & 2,488 & 10,8 \\
\hline SVT 301050 & 1393 & 32,35 & 46,23 & 43,17 & 56,83 & 2,624 & 10,4 \\
\hline СТ 101000 & 1735 & 16,95 & 30,97 & 48,20 & 51,80 & 1,948 & 9,6 \\
\hline CT 101050 & 1971 & 11,39 & 23,01 & 56,94 & 43,06 & 0,715 & 9,48 \\
\hline KRS 20930 & 1424 & 33,12 & 48,12 & 42,14 & 57,86 & 2,884 & 8,08 \\
\hline KRS 301050 & 1510 & 29,17 & 45,24 & 46,60 & 53,40 & 2,953 & 9,03 \\
\hline KBS 201050 & 1670 & 20,75 & 35,62 & 48,69 & 51,31 & 1,874 & 16,41 \\
\hline KBS 301050 & 1508 & 29,51 & 45,26 & 42,54 & 57,46 & 3,719 & 13,11 \\
\hline
\end{tabular}

Özdemir gave the porosity value of some materials in his study (Özdemir, 2002). According to this; gas concrete $74 \%$, pumice concrete $61,8 \%$, concrete $19 \%$, andesitic tuff $8,7 \%$, limestone $3,1 \%$ and granite $0,9 \%$. When the samples used in the study were compared with these materials, it was seen that the results were close to the pumice concrete value. Based on these results, it is possible to say that the samples are highly porous.

High density brick compressive strengths specified in TS EN 771-1 are given in Table 5 below. Thus, the compressive strengths of the samples produced for the experiments were compared with the help of the table. 
Evaluation of Aluminium Production Waste in Building Material Production

Table 5. Average Pressure Values of High Density (HD) Vertical Perforated Brick Units (TS EN 771-1)

\begin{tabular}{|c|c|c|c|c|}
\hline \multirow[b]{2}{*}{ Brick Type } & \multicolumn{2}{|c|}{ Compressive Strength } & \multicolumn{2}{|c|}{$\begin{array}{c}\text { Mass of Unit Volume } \\
\left(\mathrm{kg} / \mathrm{m}^{3}\right)\end{array}$} \\
\hline & $\begin{array}{c}\text { Arithmetic } \\
\text { Average N/mm² } \\
\left(\mathrm{kgf} / \mathrm{cm}^{2}\right)\end{array}$ & $\begin{array}{c}\text { Minimum } \\
\text { Value } \mathrm{N} / \mathrm{mm}^{2} \\
\left(\mathrm{kgf} / \mathrm{cm}^{2}\right)\end{array}$ & Max & Min \\
\hline \multirow{3}{*}{$2000 \mathrm{~kg} / \mathrm{m}^{3}$} & $24,0(240)$ & $19,0(190)$ & \multirow{3}{*}{2000} & \multirow{3}{*}{1801} \\
\hline & $18,0(180)$ & $14,5(145)$ & & \\
\hline & $12,0(120)$ & $9,5(95)$ & & \\
\hline \multirow{3}{*}{$1800 \mathrm{~kg} / \mathrm{m}^{3}$} & $22,0(220)$ & $17,5(175)$ & \multirow{3}{*}{1800} & \multirow{3}{*}{1601} \\
\hline & $18,0(180)$ & $12,0(120)$ & & \\
\hline & $10,0(100)$ & $8,0(80)$ & & \\
\hline \multirow{3}{*}{$1600 \mathrm{~kg} / \mathrm{m}^{3}$} & $22,0(220)$ & $17,5(175)$ & \multirow{3}{*}{1600} & \multirow{3}{*}{1401} \\
\hline & $15,0(150)$ & $12,0(120)$ & & \\
\hline & $10,0(100)$ & $8,0(80)$ & & \\
\hline \multirow{3}{*}{$1400 \mathrm{~kg} / \mathrm{m}^{3}$} & $20,0(200)$ & $16,0(160)$ & \multirow{3}{*}{1400} & \multirow{3}{*}{1201} \\
\hline & $12,0(120)$ & $9,5(95)$ & & \\
\hline & $8,0(80)$ & $6,5(65)$ & & \\
\hline \multirow{3}{*}{$1200 \mathrm{~kg} / \mathrm{m}^{3}$} & $15,0(150)$ & $12,0(120)$ & \multirow{3}{*}{1200} & \multirow{3}{*}{1001} \\
\hline & $10,0(100)$ & $8,0(80)$ & & \\
\hline & $6,0(60)$ & $4,5(45)$ & & \\
\hline
\end{tabular}

With the lowest values of $1200 \mathrm{~kg} / \mathrm{m}^{3}$ and $1400 \mathrm{~kg} / \mathrm{m}^{3}$ in terms of standard brick compressive strengths given in the table, it was concluded that all types produced in the study could be used as bricks without any additives. Again, ceramic coating material, clinker wall covering, etc. to be used in places that do not require properties in terms of pressure resistance. It was concluded that it could be a baked building material. If it is necessary to determine the optimum mixture type in terms of compressive strength; The type of black slag material added to the red mud at a rate of $20 \%$ and baked at $1050{ }^{\circ} \mathrm{C}$ (KBS 20 1050) was determined as the optimum mixture type in terms of compressive strength.

Table 6. Changes occurred in the samples at the end of the sulfuric acid bath

\begin{tabular}{ll}
\hline Sample Name & Form of Damage \\
\hline SVT 30930 & Crusty swellings over the entire surface \\
\hline SVT 301050 & Very slight swelling from the surface \\
\hline CT 101000 & No deformation was observed. \\
\hline CT 101050 & No deformation was observed. \\
\hline KRS 20930 & No deformation was observed. \\
\hline KRS 301050 & Very slight swelling from the surface \\
\hline KBS 20 1050 & No deformation was observed. \\
\hline
\end{tabular}

On the first day of the acid bath, it was observed that a very small amount of superficial swelling occurred under the influence of pure sulfuric acid (Figure 2.a). On the second day, in the acid bath, which was turned into a $50 \%$ aqueous solution with the addition of $50 \mathrm{ml}$ of water, the surface of the samples was partially more pronounced. The changes that occurred on the samples that dried at the end of the sulfuric acid bath (Figure 2.b) are given in Table 6 . 


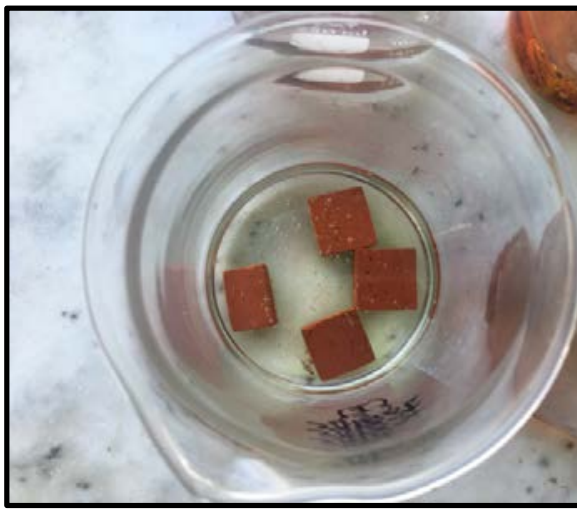

a. View of Samples in Sulfuric Acid Bath

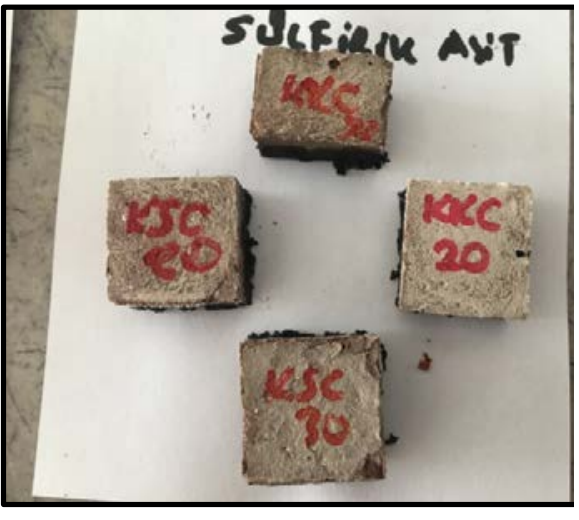

b. View of Samples After Sulfuric Acid Bath

It was observed that the acid color turned dark yellow as soon as the pure hydrochloric acid bath started (Figure 3.a). In this direction, the samples started to oscillate into the acid from the very first moment. In the first day, very obvious damages occurred in the samples (Figure 3.b). Damage observation of dried samples is given in Table 7.

Table 7. Changes occurred in the samples at the end of the hydrochloric acid bath

\begin{tabular}{ll}
\hline Samplee Name & Form of Damage \\
\hline SVT 30930 & $\begin{array}{l}\text { Although not completely disintegrated, very obvious damage has } \\
\text { occurred. }\end{array}$ \\
\hline SVT 301050 & Dispersion has occurred in the sample \\
\hline CT 101000 & Severe damage has occurred \\
\hline CT 101050 & $\begin{array}{l}\text { Damages in the form of crumbling from the surface to the inner } \\
\text { parts have occurred. }\end{array}$ \\
\hline KRS 20 930 & No significant damage has occurred, except for minor cracking. \\
\hline KRS 301050 & Very heavy comminution and disintegration have been observed \\
\hline KBS 20 1050 & Very little crusting was observed. \\
\hline KBS 301050 & Surface eroded and scattering damage was observed. \\
\hline
\end{tabular}

At the beginning of the pure nitric acid bath, a pink release occurred from the hydrochloric acid-like samples (Figure 4.a). While no obvious damage was observed in the pure acid bath, layering or deep cracks were observed on the surfaces of the samples when it became an aqueous solution. It was observed that some of the samples dried at the end of the acid bath had ruptures on their surfaces (Figure 4.b). The observation results of the damages occurring in the samples after the nitric acid bath are given in Table 8 .

Figure 2. Views from the sulfuric acid bath 
Figure 3. Views from the hydrochloric acid bath

Figure 4. Views from the nitric acid bath
Evaluation of Aluminium Production Waste in Building Material Production

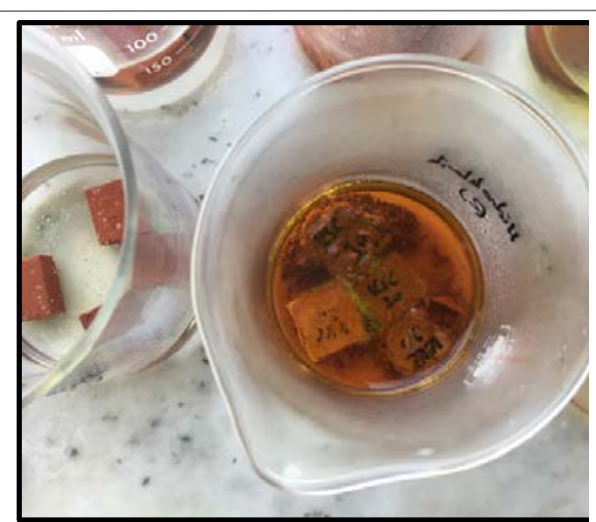

a. View of Samples in Hydrochloric Acid Bath

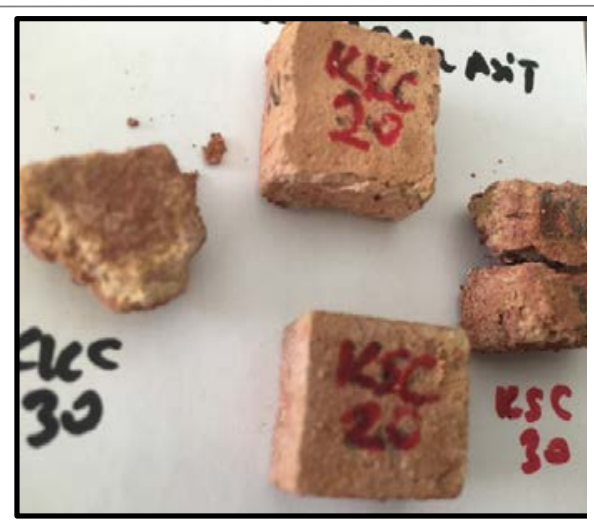

b. View of Samples After Hydrochloric Acid Bath
Table 8. Changes occurred in the samples at the end of the nitric acid bath

\begin{tabular}{ll}
\hline Sample Name & Form of Damage \\
\hline SVT 30930 & Severe damage with ruptures in the form of layers \\
\hline SVT 301050 & Severe damage with ruptures in the form of layers \\
\hline CT 101000 & Intense capillary cracks and partial ruptures \\
\hline CT 101050 & Small cracks and superficial chipping \\
\hline KRS 20 930 & Both superficial cracks and deep cracks were observed together. \\
\hline KRS 301050 & No deformation was observed. \\
\hline KBS 20 1050 & Small cracks \\
\hline KBS 301050 & No deformation was observed. \\
\hline
\end{tabular}

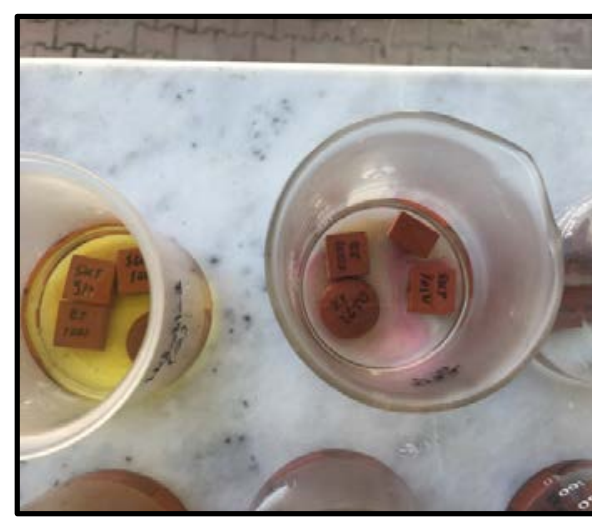

a. View of Samples in Nitric Acid Bath

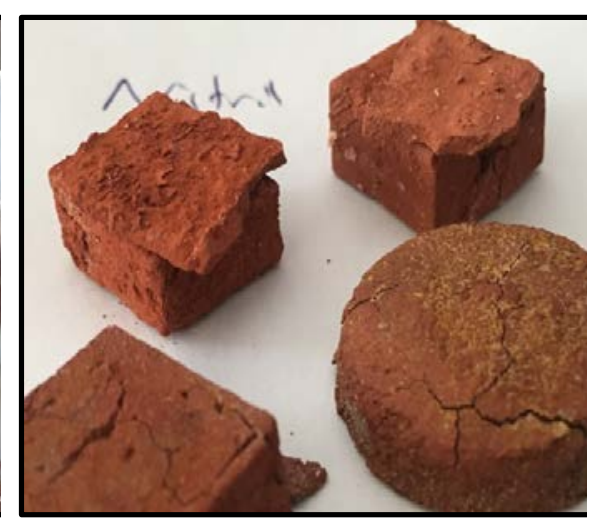

b. View of Samples After Nitric Acid Bath
Table 9. Changes occurred in the samples at the end of the phosphoric acid bath

\begin{tabular}{ll}
\hline Sample Name & Form of Damage \\
\hline SVT 30930 & Very little flaking \\
\hline SVT 301050 & No deformation was observed \\
\hline CT 101000 & No deformation was observed \\
\hline CT 101050 & No deformation was observed \\
\hline KRS 20 930 & Very dense cracks on the surface \\
\hline KRS 301050 & No deformation was observed \\
\hline KBS 201050 & No deformation was observed \\
\hline KBS 301050 & No deformation was observed
\end{tabular}

No signs of damage were observed in the pure phosphoric acid bath (Figure 5.a). No damage was observed during the bath process, which was turned into an aqueous acid solution by adding water on the second 
day. After the drying of the samples, the end of the acid bath observations were made (Figure 5.b) and the results are given in Table 9.
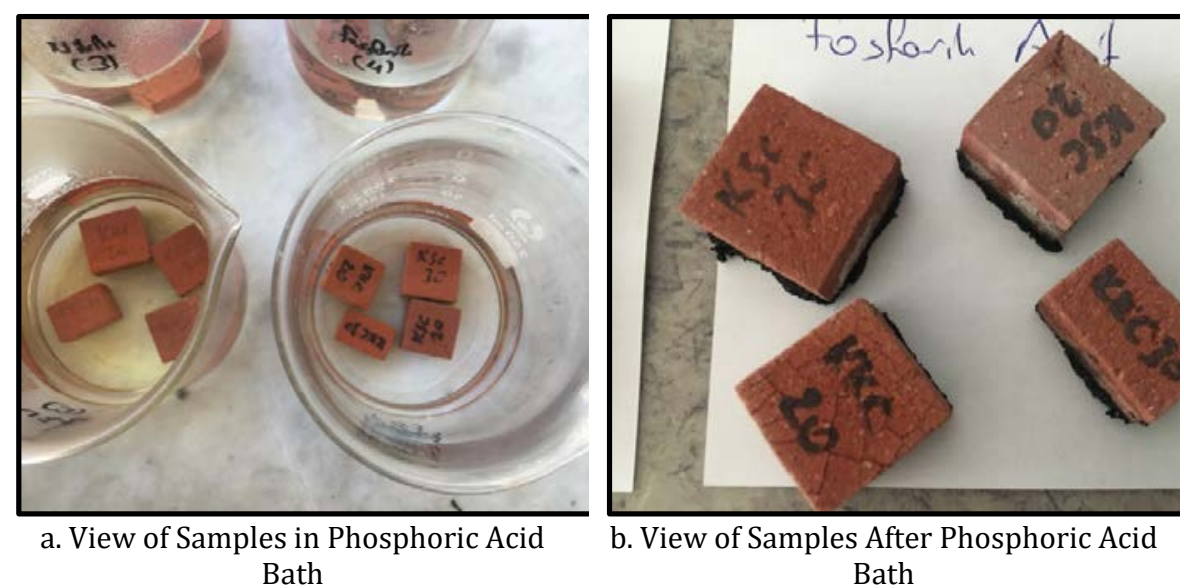

\section{CONCLUSIONS AND RECOMMENDATIONS}

The paper should also include a conclusion and recommendation section. This should identify the key issues, problems, and consequences for the findings of the research in conjunction with clear recommendations to the theory, methodology, industry, practitioners, the professions and for further research.

According to preliminary studies on raw materials and samples following results have been achieved:

- Aluminum production waste, which has a red color due to its chemical content, can be used in the production of building materials in this color,

- The plastic property of red mud is low compared to other clays. Considering that pyroclastic rocks have no plastic properties, additives must be made to increase the plastic properties of red mud,

- During the micronizing of the pyroclastic rocks, it should be calcined because the moisture in it poses a problem,

- The plaster mold system is the best method in laboratory-type sample production, but molding will not be a problem in fabricated productions,

- Baking temperatures can be used as they are, but baking at lower temperatures can be achieved with additives in terms of energy efficiency,

- As the pyroclastic addition rate increases, the total shrinkage after firing increases,

- Materials taken from all pyroclastic regions can be used in brick production by adding red mud.

The following results were obtained in the whole study for the production of sustainable building materials by micronizing the materials taken from the idle pyroclastic fields to the aluminum production waste red mud, which has effects that will harm the environment.

- It is possible to produce building materials at low temperatures,

- It is a light material, it will not bring an extra load to the structure,
Figure 5. Views from the phosphoric acid bath 
- It will be a material that can provide insulation with its high porosity and thermal insulation properties that can be improved from thermal conductivity values,

- Its mechanical strength is sufficient without making any supplemental additives,

- It is resistant to other acid effects from its behavior to strong and corrosive acids,

In this direction, it has been concluded that it is possible to produce a baked building material.

In general as a result of this study, it has been seen that red mud can be used in the production of brick (with or without bearing), which is a light, durable contemporary baked building material, as well as it can also be used in the production of building materials such as ceramics, clinker wall coverings, tiles, floor coverings, etc.

With the study, it was also concluded that red mud waste, which is a problem for sustainable environment, can be consumed by using high rates. It has been seen that it will meet some of the modern building material needs for sustainable building. And it has been seen in the literature studies that there are ways to make it possible to recycle the material produced in line with the work on behalf of sustainable building material, if it completes its useful life. Again with the study, the use of idle pyroclastic fields will be opened and contribution to the economy will be made.

\section{ACKNOWLEDGEMENTS/NOTES}

This study was prepared by utilizing the doctoral thesis titled "Investigation of the Effects of Micronized Pyroclastic Addition to Red Sludge for the Production of Sustainable Building Materials" made by Mustafa DERELI under the supervision of Mustafa TOSUN and completed in May 2019.

There is a patent application numbered 2020/00625 on behalf of Mustafa Dereli for research.

\section{CONFLICT OF INTEREST}

No conflict of interest was declared by the authors.

\section{FINANCIAL DISCLOSURE}

The authors declared that this study has received no financial support.

\section{ETHICS COMMITTEE APPROVAL}

There is no element that requires ethical committee approval.

\section{LEGAL PUBLIC/PRIVATE PERMISSIONS}

In this research, the necessary permissions were obtained from the relevant participants (individuals, institutions, and organizations) during the survey, indepth interview, focus group interview, observation, or experiment. 


\section{REFERENCES}

Arroyo, F., Luna-Galiano, Y., Leiva, C., Vilches, L. F., \& Fernandez-Pereira, C. (2020, Jul). Environmental risks and mechanical evaluation of recycling red mud in bricks. Environmental Research, 186. https://doi.org/ARTN 109537 10.1016/j.envres.2020.109537

Arslan, S., Demir, G. K., Celikel, B., Baygul, M., \& Suarez, C. E. (2012). Eti Aluminum Red Mud Characterization and Processing. Light Metals 2012, 81-85. <Go to ISI >://WOS:000324538600015

ASTM_C67-11. (2011). Standard Test Methods for Sampling and Testing Brick and Structural Clay Tile. ASTM International.

ASTM_C109. (2001). Standard Test Method for Compressive Strength of Hydraulic Cement Mortars (Using 2-in. or [50-mm] Cube Specimens). ASTM International.

Dereli, M., \& Tosun, M. (2020, Sep 5). Analysis of the effects of adding pyroclastic rock to red mud for the production of a baked building material in terms of its resistance to frost actions. Sn Applied Sciences, 2(10). https://doi.org/ARTN 1632 10.1007/s42452-020-03472-w

Helvacı, C., \& Erkül, F. (2001). Volkaniklastik Kayaçlar Oluşumu, Genel Özellikleri ve Sınıflaması. Dokuz Eylül Üniversitesi.

Li, Y. C., Huang, H., Xu, Z., Ma, H. Q., \& Guo, Y. F. (2020, Apr 20). Mechanism study on manganese(II) removal from acid mine wastewater using red mud and its application to a lab-scale column. Journal of Cleaner Production, $253 . \quad$ https://doi.org/ARTN 119955 10.1016/j.jclepro.2020.119955

Malayoğlu, U., \& Akar, A. (1995). Killerin Sinıflandırmasında ve Kullanım Alanlarının Saptanmasında Aranan Kriterlerin Irdelenmesi Endüstriyel Hammaddeler Sempozyumu, İzmir.

Olanca, K. (1999). Karapınar-Konya Yöresi Kuvaterner Volkanizması: Jeokimyasal Yorum. Hacettepe Üniversitesi Yerbilimleri Dergisi, 21, 115124.

Özdemir, A. (2002). Bazı Yapı Malzemelerin Kapiler Su Emme Potansiyelleri. Jeoloji Mühendisliğii, 26, 19-32.

Saternus, M. (2011). Bayern's Method of Al203 Production - Possibilities of Red Mud Disposal and Utilization. Light Metals and Their Alloys I: Technology, Mocrostructure and Properties, 176, 11-20. https://doi.org/10.4028/www.scientific.net/SSP.176.11

TS_699. (2009). Tabii Yapı Taşları- Muayene ve Deney Metotları. TSE.

TS_1900-1. (2006). Zemin Malzemesi Fiziksel Özelliklerin Tayini, İnşaat Mühendisliği Zemin Laboratuvar Deneyleri. TSE.

TS_EN_771-1. (2005). Kil Kagir Birimler-Özellikler. TSE.

TS_EN_772-1. (2012). Kagir Birimler-Basınç Dayanımının Tayini. TSE.

TS_EN_772-11. (2002). Kagir Birimler-Deney Metodları: Betondan, Yapay Ve Doğal Taştan Yapılmış Kagir Birimlerde Kapiler Su Emme Ve Kil Kagir Birimlerde İlk Su Emme Hızının Tayini. TSE.

TS_EN_772-13. (2002). Kagir Birimler Deney Metodları: Kagir Birimlerde Net ve Brüt Yoğunluk Tayini. TSE. 
TS_EN_15309. (2008). Characterization of waste and soil - Determination of elemental composition by X-ray fluorescence. TSE.

TS_EN_ISO_11358-1. (2014). Plastik - Polimerlerin Termogravimetri Analizi, Plastikler- Genel. TSE.

TS_EN_ISO_17892-3. (2016). Tane Yoğunluğunun Belirlenmesi, Geoteknik Etüd ve Deneyler. TSE.

Wang, Y. N., Tian, X., Zhao, H. B., \& Liu, K. L. (2020, Aug). The use of a lowcost oxygen carrier prepared from red mud and copper ore for in situ gasification chemical looping combustion of coal. Fuel Processing Technology, 205.2 https://doi.org/ARTN 106460 10.1016/j.fuproc.2020.106460

Winkler, D., Bidlo, A., Bolodar-Varga, B., Erdo, A., \& Horvath, A. (2018, Dec 10). Long-term ecological effects of the red mud disaster in Hungary: Regeneration of red mud flooded areas in a contaminated industrial region. Science of the Total Environment, 644, 1292-1303. https://doi.org/10.1016/j.scitotenv.2018.07.059

Xiang, W. H., Ding, Q. J., \& Zhang, G. Z. (2020, Jan-Feb). Preparation and characterization of porous anorthite ceramics from red mud and fly ash. International Journal of Applied Ceramic Technology, 17(1), 113-121. https://doi.org/10.1111/ijac.13148

Yuan, B., Yuan, S. S., Straub, C., \& Chen, W. (2020, Feb 1). Activation of Binary Binder Containing Fly Ash and Portland Cement Using Red Mud as Alkali Source and Its Application in Controlled Low-Strength Materials. Journal of Materials in Civil Engineering, 32(2). https://doi.org/Artn 04019356 10.1061/(Asce)Mt.1943-5533.0003023

Yuan, S., Liu, X., Gao, P., \& Han, Y. X. (2020, Jul 15). A semi-industrial experiment of suspension magnetization roasting technology for separation of iron minerals from red mud.Journal of Hazardous Materials, 394. https://doi.org/ARTN 122579 10.1016/j.jhazmat.2020.122579

Zhang, J., Li, S. C., Li, Z. F., Liu, C., \& Gao, Y. F. (2020, Sep). Feasibility study of red mud for geopolymer preparation: effect of particle size fraction. Journal of Material Cycles and Waste Management, 22(5), 1328-1338. https://doi.org/10.1007/s10163-020-01023-4

\section{Resume}

Mustafa Dereli works as a research assistant doctor at Konya Technical University, Department of Architecture. Dereli received MSc in Department of Architecture in 2004 from Selcuk University, Konya, Turkey. And he received PhD in 2019 on Using Industrial Waste for Sustainable Building Materials at Konya Technical University, Department of Architecture, Konya, Turkey.

Mustafa Tosun is a professor at Konya Technical University, Faculty of Architecture and Design, Department of Architecture. He supervised the thesis on which this study was used. He still trains students in the field of Building Information. 